\title{
Sustainable decentralised wastewater treatment schemes in the context of Lobitos, Peru
}

Christiana Smyrilli BA, MEng, MRes, MA

PhD Researcher, University of Cambridge, Cambridge, UK (corresponding author: cs650@cam.ac.uk) (Orcid:0000-0001-9398-6443)

Sivasakthy Selvakumaran MEng, CEng, MICE

PhD Researcher, University of Cambridge, Cambridge, UK

(Orcid:0000-0002-8591-0702)

Michael Alderson BSC, MSC

Director, Environmental Sustainability, EcoSwell UK, Newcastle, UK

\author{
Alejandro Pizarro BSC \\ Director, Research and Communications, EcoSwell Peru, Lima, Peru \\ Diego Almendrades BSC \\ Director, Sustainable Development, Finances \& Economy, EcoSwell Peru, \\ Lima, Peru \\ Britanny Harris MEng \\ Engineer, BuroHappold Engineering, Bath, UK \\ Andres Bustamante $\mathrm{BComm}$ \\ Director, Marketing and Public Relations, EcoSwell Peru, Lima, Peru
}

The implementation of decentralised wastewater treatment systems, such as biodigesters, septic tanks and treatment ponds, provides opportunities for rural or remote communities to be self-reliant and avoid infrastructural connections to faraway urban areas. However, the effectiveness, sustainability and success of such systems is heavily tied to understanding the overall context (geographical, social, cultural, political and economic) in which they are installed, as well as the ease of their operation and maintenance in the long term. Shortcomings to addressing these aspects can lead to the failure of a project. Using the town of Lobitos, located in the Piura District on the northern coast of Peru, as the case study for this research, this paper is discussing and analysing the use of biodigesters as a more sustainable solution over larger municipal wastewater systems in the context of Lobitos. It explains reasons, such as community engagement, behind past failures of such systems and outlines lessons learned from a practitioner's perspective. It concludes that addressing the local context as well as considering its impact throughout the project cycle, such as installation and future operation and maintenance, helps to ensure continued delivery of safe and sustainable wastewater treatment.

\section{Introduction}

Decentralised wastewater treatment systems (Dewatss) are systems that treat wastewater close to the source, compared to centralised wastewater treatment systems which transport large amounts of wastewater long distances through sewers in order to reach the treatment facility. They typically collect small volumes of domestic wastewater to the treatment location using pipes and can be used to treat the effluent from individual homes or clusters of homes, as well as businesses. Additionally, centralised systems are generally located near surface bodies of water, where the treated water will be disposed, while the Dewats' location is determined by the presence of the source of the wastewater. They generally disperse treated waste into the soil, which can provide further treatment, or may also discharge their output into open surface water bodies (US EPA, 2005a).

Dewatss are not a novel concept and have been considered for a while as a potentially viable option for strengthening current wastewater treatment systems (Libralato et al., 2012). The decentralised approach for wastewater treatment allows flexibility in management and a combined approach of different technologies in both simple and more complex scales (Massoud et al., 2009). Various technologies and systems are well developed and documented and are easily available on the market. For example, biodigesters use bacteria for the anaerobic breakdown of pathogens that are present in the wastewater, producing biogas, which, in an energy-sanitation integrated system, can be used to produce energy, as well as fertilizer for agriculture (An et al., 1997; Moog et al., 1997; Rose, 1999). Treatment ponds are another example of decentralised systems and exist in various designs (Garfí et al., 2017), each having different treatment methods (aerobic or anaerobic) and processing times, which need to be taken into account when implemented in communities (Gutterer et al., 2009a). Dewatss provide a more appropriate and sustainable wastewater treatment solution (Balkema et al., 2002) and may overcome some of the problems encountered by larger-scale alternatives, such as maintenance issues, since Dewatss are usually simpler in design, or operation issues during power cuts (Gutterer et al., 2009b).

Changes in population trends, such as the increasing tendency for populations to concentrate around urban centres (UN, 2015), and changes in future climate patterns, such as changes in global surface temperatures (Thorne, 2017), a rise in sea levels (Slangen et al., 2016) and an increased risk in precipitation and flooding due to sea surface temperature changes (Trenberth, 2011), give rise to the argument for infrastructure solutions that are flexible and able to adapt to various uncertain future scenarios (Abraham et al., 2017). Peru itself has seen the impact of such changes in the last years, with extreme rainfall and flooding during the El Niño in 2016, where the infrastructure was unable to cope with the increased rainfall and changing climatic conditions (L'Heureux et al., 2017; 
Sanabria et al., 2017; Taj, 2017). Under these changing patterns, scientists are already beginning to look into the integration of smaller-scale Dewatss as a more flexible solution (Lijó et al., 2017). Such solutions have plenty of scope to grow and adapt as a network and offer the additional benefit of modularity meaning that in the event of a failure, only one portion of the network is off line, reducing disruption to the overall operation.

Beyond the careful selection of suitable technologies, Dewatss still risk failure if consideration is not made towards the context in which they are installed or the manner by which they will be operated, financed and maintained in the future (Carter et al., 1999; Hazeltine, 2003). Failure to address these issues may lead to negative impacts that can range from detrimental health impacts through contact with untreated or poorly treated water (Bartram and Baum, 2015; Bartram and Cairncross, 2010; Cairncross et al., 2010; Carter et al., 1999), to environmental pollution within the local watershed, such as the recharge of groundwater reservoirs contaminated with faecal matter from the wastewater (Asano and Cotruvo, 2004). These considerations should also include strategies for management and for engaging end users into the maintenance process of the systems and enable them to resolve problems that may arise, in order to capitalise on local knowledge and ensure the sustainability of the projects through the community feeling of ownership (Manikutty, 1997).

This paper is looking at how the aforementioned considerations impacted projects in Lobitos, Peru, and how the local context determines the sustainable implementation of a Dewats.

\section{Methodology}

This article presents the findings of the authors, presenting a practitioner's perspective on the sanitation and waste management systems in the town of Lobitos. Information presented in this article was collected through participatory action (Baum et al., 2006), where the authors have all lived and worked within the community of Lobitos, for varied lengths of time between 2013 to present, in order to understand the local context and the current situation around sanitation and wastewater treatment. Data were collected through meetings and interviews with key stakeholders of the community, mainly institutional groups such as the Fishermen's Guild (FG). The older members of the community are the primary informants of local knowledge of the history of Lobitos, contributing qualitative data through narratives, to formulate a picture of the background context of the community. Additionally, a quantitative survey was carried out by the authors in 2015 to identify the current wastewater treatment service of households. Workshops and focus groups with the FG took place, to establish community engagement and participation to the proposed project. The FG was identified as the community group where the new biodigester system would be installed by the organisation where the authors worked, as it is the only grassroots organisation in the town with 143 members. The building, which acts as headquarters for the guild, is used daily as an office for the guild's president and the district governor, averaging a population of 10 people at any time, and weekly for workshops, meetings and social events, where it may host up to 100 people. Finally, meetings with the local authorities of the municipality and the nearby town of Talara were established in order to collect data on past sanitation projects, as well as to understand the influence of governmental bodies on the development of the town's sanitation systems. The following sections present the findings of the authors, giving an overview of the background history of Lobitos, the current situation around sanitation and finally closing with lessons learnt from a past biodigester project, analysing the factors that influenced the outcomes and how these were accounted for in the installation of a new biodigester at the FG.

\section{The history and local context of Lobitos, Peru}

Lobitos is a small town in the coastal Piura region of northern Peru, $17 \mathrm{~km}$ from the city of Talara, with a population of around 1600 people (INEI, 2011), with the men being primarily artisanal fishermen and the women primarily engaging in housework (Sánchez 2013). Upon discussion with the locals, it was outlined that other economic activity includes housekeeping in hotels, trade jobs and small local businesses such as local women cooking and selling food and a large portion working for the municipality as local security and municipal police and employed as workers for the reforestation programme. The town is located in an arid area, with the average precipitation being about $20 \mathrm{~mm}$, and November being the wettest month (World Weather and Climate Information, 2016). This causes water scarcity in Lobitos, as demonstrated by narratives of the locals, meaning that the town needs to import water from the nearest source, the river Rio Chirra, located $170 \mathrm{~km}$ south of the town, in the Piura District (Sánchez, 2013). This highlights the opportunity of using a local Dewats for recycling and reusing water in the area, increasing water security in the area by treating wastewater locally for reuse in irrigation.

The growth of oil and extractive industries in the early 1900s (Petroblogger.com, 2013) led to Lobitos becoming a prosperous place, with a booming economy, an increased population of more than 2000 inhabitants and good infrastructure provided and built by the oil industry. According to narratives by the locals, a change in the political climate around the 1960s resulted in the expulsion of much of this industry, causing a decline in economic investment in Lobitos and a population decrease to around 1500. As stated, this left the area vulnerable to serious issues around water, sanitation, waste management and poverty due to a drop in skilled workforce that had been previously brought in by the oil companies, which left the infrastructure abandoned and unmaintained. For example, talks with local experts from nongovernmental organisations (NGOs) stated that water tests carried out in 2016 by water quality experts have shown the noncompliance of the water quality with health standards, confirming concerns about the water quality resulting from a poor state of repair of the distribution system.

Starting in the 2000s, the socioeconomic profile of the town started changing again due to an emerging tourism economy, 
bringing interest and attention to the area, with about 2000-3000 people visiting Lobitos every year, based on estimates from local hotel owners. Observations by the locals and the authors suggest that 50-300 tourists visit Lobitos at any time, most locals visiting during the summer, while most of the international tourists come during the winter months due to the surfing waves. This surge in surf tourism brings both financial investment and employment opportunities to the local economy, with some locals taking up the role of surfing instructors and creating new markets. Despite the positive economic impacts, the influx of tourists poses a threat to the environment and the infrastructure, in the absence of sustainable practices. This rapid growth in population puts a strain on the wastewater treatment facilities and exacerbates current problems, as their capacity is limited and the infrastructure is ageing. This again poses an opportunity for Dewats that can be implemented locally to treat increased wastewater during periods of high influx of tourists.

\section{Discussion of current wastewater treatment systems in Lobitos}

\section{Failures of existing systems}

Lobitos is serviced both by a centralised municipal system, which displays a number of issues and inefficiencies, and by private decentralised systems. These are analysed in this section, based on data collected during interviews with the locals and government officials.

\section{Municipality (mis)service}

According to the survey results, $70 \%$ of Lobitos is connected to the sewer system, which was constructed in the 1920s. The wastewater is mainly composed of toilet flush sewage, sink water and shower water. It is estimated that some of this wastewater is distributed by way of concrete pipes to various cesspits located around Lobitos and remains untreated, while most of it accumulates into spill points (marked as sewage spill points in Figure 1) due to burst pipes. This open-surface wastewater pools pose health risks to the inhabitants, while they also infiltrate the ground causing pollution and environmental issues to the local

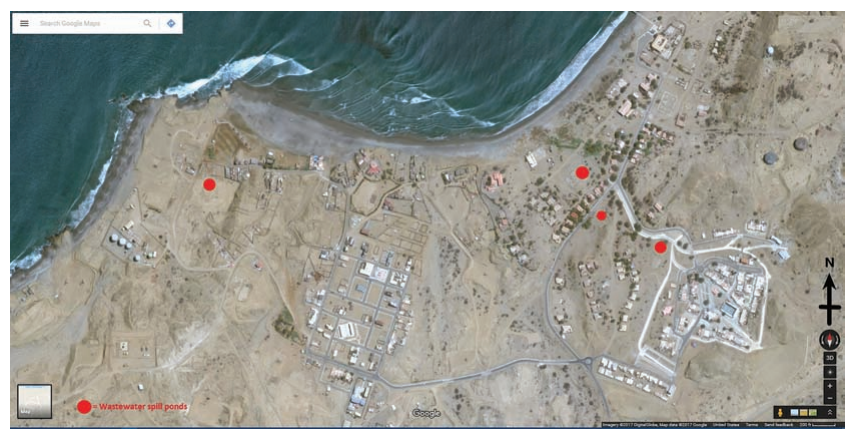

Figure 1. Map of Lobitos and locations of wastewater spill points due to burst sewage pipes, each estimated to cover a surface area of 2-4 $\mathrm{m}^{2}$ (base map imagery taken from Google Maps) area. The spill points are pumped out on a regular basis, on average every 2 months, by a state-owned water utility company, EPS Grau, which is paid by the municipality, for treatment at the company's wastewater treatment plant and oxidation ponds in Talara, which is inefficient and costly. As the sewerage infrastructure is not well maintained, as evidenced by the observed increase in number of untreated wastewater pools due to breaking pipes, the system does not operate adequately. This indicates an institutional failure in dealing with wastewater treatment.

In an attempt to solve the aforementioned issues, oxidation ponds were built by the municipality of Lobitos in 2010, with the intention of treating the community's wastewater from the sewer system. Through discussions with municipality officials, a number of problems were identified as factors of the failure of this project. These ponds are located approximately $1 \mathrm{~km}$ north of the town, and therefore, pumps were installed to transport the wastewater to the oxidation ponds. However, the pumps installed by the municipality to move the wastewater to the ponds required a three-phase electrical power source, but unfortunately, the local electricity grid is limited to a single-phase power, and so they were unable to be used, showing a lack of skill and knowledge within local, formal government structures. Furthermore, the pumps were stolen before there was an opportunity to replace them, indicating that crime and corruption are present challenges. Additionally, municipal elections happened and the administration responsible for the project changed, without the motivation to continue with the project, showing the importance of political power on these projects. Finally, additional financial investment would be required to re-establish the oxidation ponds to a functioning state, which decreases the willingness of the local municipality to restart working on the project.

Most of the households, which are not connected to the sewer system ( $22 \%$ of the total number of households in Lobitos), have constructed their own cesspits or share cesspits between two or three houses, which have their own problems as sanitation systems. They are prone to leaching into the ground due to improper or insufficient water proofing, resulting in environmental pollution and contamination. Moreover, when these septic tanks get full, the owners cover them and dig a new one, as they cannot afford to pay for the private company to pump out the wastewater. This leaves the untreated wastewater in the ground for long periods of time and risks exposure or further leaking of contaminants into the ground.

Finally, $8 \%$ of the households, accounting for $100-150$ people, located in the northern section of the town, do not have access to the sewer system nor have they been able to afford the construction of a cesspit. These families resort to open defecation, exposing themselves to health and environmental risks, as this leaves waste exposed and untreated (Cairncross et al., 2010). Furthermore, as noted by locals, social stigmas are associated to open defecation, particularly affecting women both 
psychologically and from a health perspective (Burt et al., 2016; Sahoo et al., 2015).

\section{Biodigesters}

Biodigester refers to anaerobic treatment systems that treat wastewater biologically by means of filtration and septic degradation of organic matter (US EPA, 2005b). Lobitos has had an experience with two biodigesters (Figure 2) as public Dewats solutions, installed in the past by a local NGO (different to the one the authors worked with). One of these biodigesters was installed in the school in Lobitos in July 2015 to treat its sewage. This is used here as a case study to identify how considerations of the local context, installation, operation processes and future use can lead to the success of such systems.

Upon inspection by local experts, the school biodigester poses health and environmental risks due to non-compliance with the guidance and standards and lack of communication with the local community. It was found that the treated wastewater from the biodigester was being used for the surface irrigation of ornamental and medicinal plants, which had a number of negative implications. Firstly, the wastewater was not treated to the full extent in order to make the end product suitable for surface irrigation, as the biodigester gives only a primary treatment to the wastewater, leaving it with significant levels of pathogens. The manufacturer's manual states that for this particular biodigester, only the underground irrigation of plants should take place, and wastewater treatment should be completed by filtering into the ground through underground pipes or absorption shafts. The end users had not been properly informed on its operations and maintenance requirements, showing that the lack of communication and information allocation results in negative impacts to community members. Secondly, in some instances, surface irrigation was carried out by schoolchildren who would manually carry the water and risk coming into contact with the effluent, which, according to the manufacturer, is not suitable for direct human contact as it poses a health risk. Finally, this particular biodigester generated an unpleasant smell, probably due to bad ventilation, which was a complaint voiced by staff, students and parents of the school, while the local, not-for-profit organisation that installed the biodigester did not provide guidance on future use and maintenance. On investigation into the installation procedure and manufacturer's guidelines, it was found that if a biodigester was installed and used properly, it would not generate odours and that this particular biodigester had been installed by someone without any expertise, on the assumption that a standard product would be straightforward to install, operate and maintain.

This example shows that a decentralised wastewater system could result in additional health risks and/or issues if it is not installed properly, and the future use and maintenance is not considered.

\section{Environmental factors}

The inadequacy of the current systems, from a technical and management perspective, is evident through the issues outlined above. However, changing climate conditions pose an additional challenge as the recent floods in 2017 have indicated (Figure 3). The heavy rains during the months of February and March were attributed to abnormally high temperatures in the Pacific Ocean (Trenberth, 2011).

Biodigester - conceptual diagram

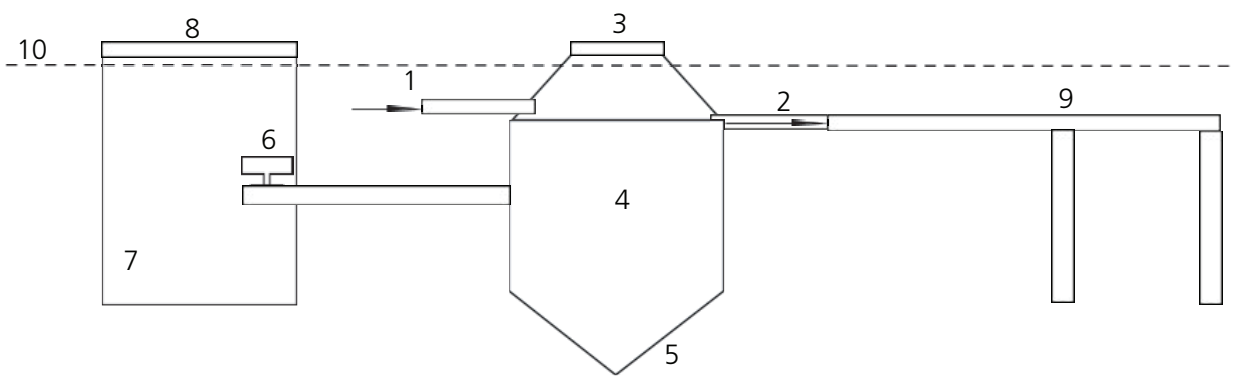

1 - Black water inlet pipe in to biodigester (from sewer)

2 - Treated water exit into filtration camp or soak away. Automatic continuous flow: as black water enters, treated water exits.

3 - Biodigester lid above ground (everything else is buried)

4 - Biodigester (polyethylene) filled with plastic rings (PETS) for filtering. In this chamber, the waste is collected and naturally occurring microorganisms breakdown the solids into safe effluent of non-toxic sludge.

5 - Conic base for accumulation of sediments

6 - Valve for extraction of treated sediments. Opened once every half a year or every year depending on usage.

7 - Concrete chamber (bottom less so that water can filter into the terrain) for drying up treated sediments and protecting the extraction valve. Once dried, the sediment 'bricks' can be used as fertilizer or 'humanure' for ornamental plants/trees.

8 - Chamber lid above ground (everything else is buried)

9 - Filtration camp pipes for treated water to filter into the terrain. Can irrigate ornamental plants/trees through underground drip irrigation.

10 - Ground line.

Figure 2. Outline illustration of how the installed biodigesters should function 


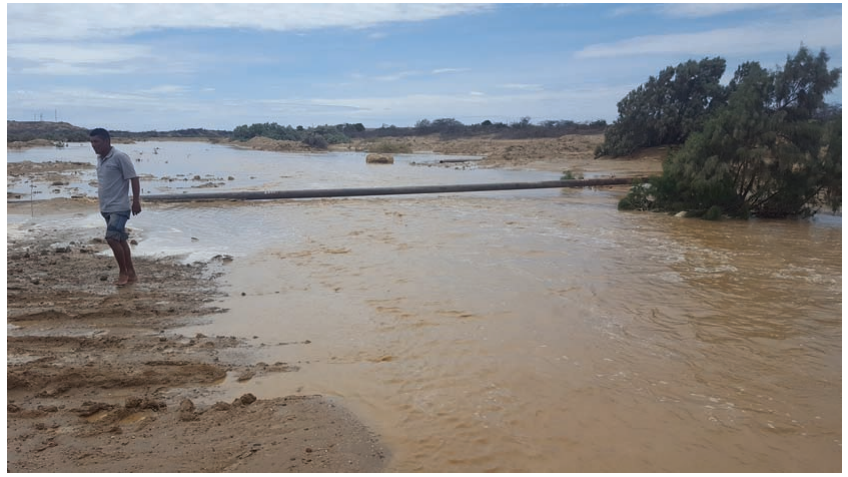

Figure 3. Flooding damages key water pipeline into Lobitos in 2017

The floods exacerbated the problems with the already collapsed centralised wastewater system. The seepages from this collapsed system, which had turned into sewage ponds, were carried by the floods to further parts of the town, increasing the risk of exposure to harmful waste and posing a health hazard in the locality. In contrast, upon inspection by local experts, existing smaller decentralised systems, such as the private septic tanks and the installed biodigesters, did not present any operational issues during this period, as they were installed on higher ground. This suggests that a well-implemented Dewats could be a more practical solution in a location in which larger centralised systems are not operating in an optimal manner.

\section{A new biodigester}

Based on the lessons learnt from the Lobitos school biodigester project, and additional information gathered from the community, a number of requirements have been established for future biodigester projects. The authors took these lessons and used them in the design of a new biodigester project in Lobitos. It was established through discussions with the local community that an improved sanitation solution was required at the FG community hall, which is a landmark building within the community, as it acts as a meeting space for important community discussions. Furthermore, it is believed that using the FG as an example, this would promote the use of wastewater treatment systems for the wider area of Lobitos.

To date, sewage from the bathrooms is being released into the environment through the spill ponds because it is not connected to any of the septic tanks, and as previously mentioned, there is no treatment facility currently in Lobitos. The installation of a biodigester, which was chosen as a simple and affordable solution, was identified as an appropriate technology to ensure that the contamination from this community hall was removed and to avoid contributing to the release of pathogens and people getting sick. It was also identified that a wide area of land adjacent to the site belongs to the fishermen and is therefore available to lay the necessary filtration pipes, and it provides the opportunity for future expansion and development.
The biodigester was chosen as it was accepted by the community due to their experience with the previous biodigesters installed and also because it is available for purchase at a specialised store in Talara. In this particular example, the appropriate size of the biodigester $(70001)$ was calculated by considering the times when the hall is used at maximum capacity (100 people). The biodigester was chosen to be able to cope with this capacity in order to ensure proper treatment all the time. Given the appropriate capacity of an off-the-shelf biodigester solution, and the cost efficiency in purchasing a standard product, this was elected as the solution. However, it has already been established that the success of a scheme is not guaranteed solely by the use of an appropriate technology. Understanding the wider context in terms of local skills, availability and needs, in combination with training and an operation and maintenance plan of the technology itself, is required to ensure the long-term success of the project.

During the whole installation process, every step mentioned in the manual was closely followed, and a technical expert was sent by the biodigester manufacturer for the final stage of installation to support the installation process and ensure quality. Photographs taken during the installation of the biodigester at the FG can be seen in Figures 4 and 5. A local worker with experience installing other biodigesters in Lobitos was also hired and was present throughout the whole process. The presence of these skilled workers ensured a means of quality assurance during the installation. A wooden fence-like structure was built around the area of the installed biodigester to prevent motorised vehicles from driving over the buried equipment and damaging it (Figure 6). Taking on lessons learned from other schemes, a ditch was built to let rainwater runoff instead of accumulating on top of the buried biodigester.

The president of the FG and its key members, who are more literate, were expected to be more likely to look after it due to the pride of ownership of the biodigester and have been trained and given instruction handouts and manuals regarding its appropriate use and maintenance to ensure its long-term use. Warning signs have been hung at every toilet bowl to prohibit using hydrochloric

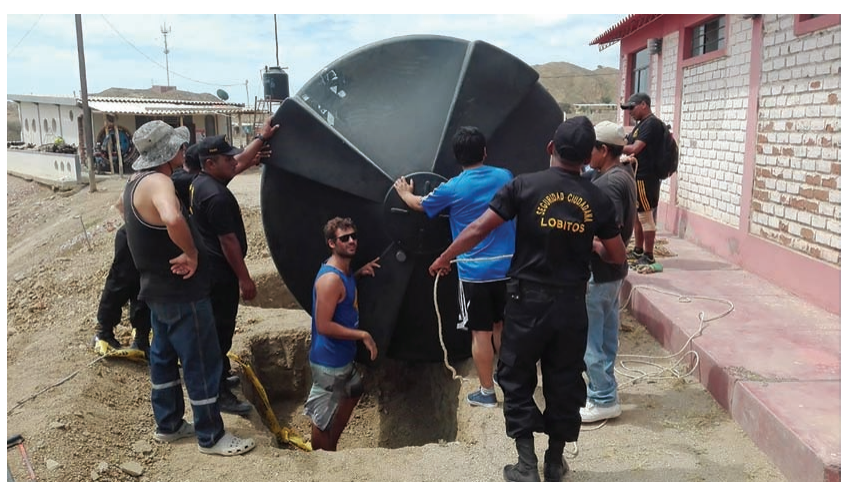

Figure 4. Installation of biodigester at the Lobitos FG 


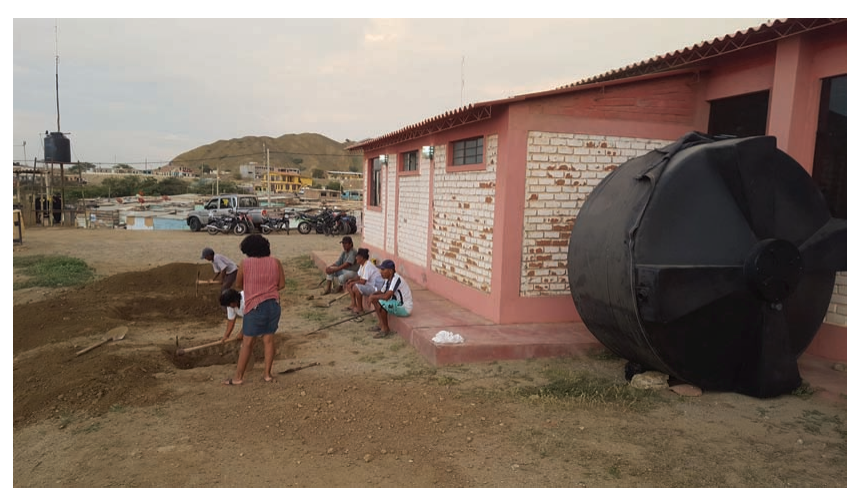

Figure 5. Installation of biodigester at the Lobitos FG

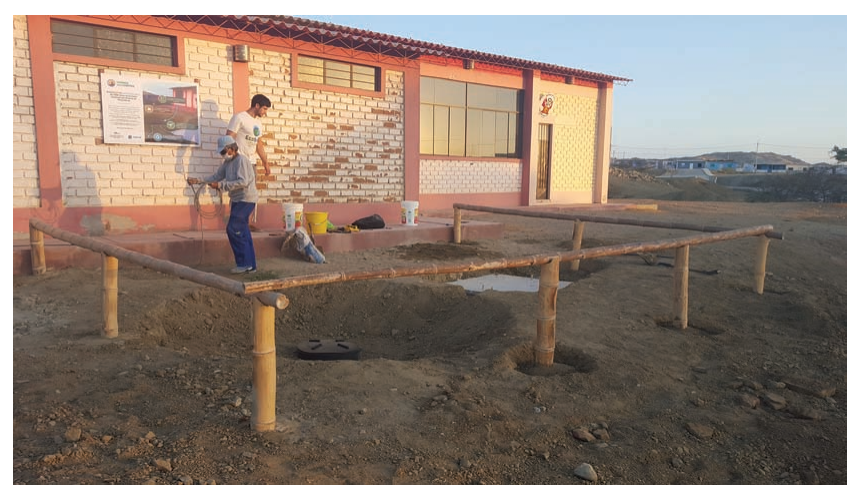

Figure 6. Completed installation of biodigester with fencing protection

acid when cleaning (a common practice in Peru) as per the manufacturer's guidelines, to avoid irreparable damage to the biodigester. Other cleaning products that are allowed are mentioned in the signs. The first scheduled maintenance works for the biodigester was undertaken after 1 year of use. This included the team involved in the installation, together with the guild's president and other guild members, to ensure that this knowledge is passed onto the guild community for future years, and any further lessons learned would be disseminated across the team involved.

The decision to install a biodigester was made as part of a wider infrastructure strategy taking into account community needs and how it fits within the existing and potential future infrastructure. For example, the installation of such wastewater treatment systems connects to the desire of the local population to find solutions to reuse water as well as reuse treated wastewater for the irrigation of plants and trees. This was derived through a broader piece of work comprising a social assessment in which different groups within the population were consulted. The survey found that, generally, the people wanted a greener town, linking a greener town to a happier and higher quality of life. Trees were planted at the outlet of the biodigester to check the irrigation capabilities of the effluent and have demonstrated positive results as the trees have been growing using the treated water. Highlighting that the decentralised wastewater treatment initiatives is not only good practice, but also a direct contribution to the community's broader goals aids in encouraging the ownership of such schemes.

\section{Future risks going forward}

A number of risks to the success of the biodigester scheme have been identified, and actions to either mitigate or monitor these risks have been put in place. One risk is the change in administration and involvement of less-knowledgeable people. Whenever a new FG administration comes in, they are properly informed by the previous one on operation and maintenance during handover. Additionally, it has been found that the current (newly elected) guild president does not manage the water of the community hall appropriately and the toilets sometimes go months without water or cleaning. Thus, the biodigester risks failing due to insufficient usage and no influence to 'feed' it, which raises the issues of continuity and sustainability of the project and suggests that a better management system within the institution of the guild should be established. To avoid the failure of the system, training and education around such risks must be effectively communicated so that those in charge of maintenance have an appreciation of the longer-term cost implications of not investing time in the present smaller-scale maintenance actions.

The context of this community includes a complex interface with local governments, municipal governments, armed forces and corporate stakeholders (Table 1). Part of this complex interaction includes land rights. Despite the adjacent land being owned by the FG, the municipality has previously overridden these rights and undertaken construction works in this area. Presently, this area has buried filtration pipes, which risk damage if such an event occurs in the future. For this reason, the stakeholders involved extend beyond the FG (owners/operators), and part of this project involved interaction with various other bodies in order to convey the impact of actions such as construction works in the biodigester area and what it means to the success of the Dewats. The long-term success and sustainability of Dewats is dependent on the long-term transfer of knowledge within the communities where they are implemented, so that technologies can be constructed, implemented, managed and maintained effectively. In the example of this project, the long-term maintenance and performance of the biodigester is the responsibility of the guild, but the overall success of the project is affected by a number of other people who may affect the land surrounding the site.

Another concern is the exposure of the pipes above ground, which indeed happen with this biodigester in the period since installation. This occurred due to the more recent erosion of the ground during the heavy rains caused by the El Niño climate effect. In this instance, none of the parts where wastewater filters through was exposed and no wastewater was found to emerge at 
Table 1. Map of stakeholders and interested parties in Lobitos

\begin{tabular}{|c|c|c|c|}
\hline $\begin{array}{l}\text { Public sector } \\
\text { institutions }\end{array}$ & Private organisations & Grassroots organisations & $\begin{array}{l}\text { Academic } \\
\text { organisations }\end{array}$ \\
\hline $\begin{array}{l}\text { Municipality of } \\
\text { Lobitos }\end{array}$ & Private companies & Fishermen's Families of Lobitos & Peru \\
\hline $\begin{array}{l}\text { Educational and Culture } \\
\text { Department }\end{array}$ & BNP Paribas Cardif & Fishermen's Association of El Alto & $\begin{array}{l}\text { Pontificia Universidad } \\
\text { Catolica del Peru }\end{array}$ \\
\hline $\begin{array}{l}\text { Environmental } \\
\text { Department }\end{array}$ & Enel Energy & Fishermen's Association of El Nuro & Universidad del Lima \\
\hline Accounting Department & Columbus Zoo & Fishermen's Association of Lobitos & $\begin{array}{l}\text { Universidad Peruana de } \\
\text { Ciencias Aplicadas }\end{array}$ \\
\hline Major's Office & Sapet Development & $\begin{array}{l}\text { Neighbour's Association of the } \\
\text { Military Villa }\end{array}$ & Colegio Altair \\
\hline Communication's Office & Waira Energy & Neighbour's Association of Bellavista & \\
\hline $\begin{array}{l}\text { Municipal Manager's } \\
\text { Office }\end{array}$ & RotoPlas & Farmer's Community of Piedritas & UK \\
\hline \multirow[t]{2}{*}{$\begin{array}{l}\text { Fishermen's Office } \\
\text { (at the pier) }\end{array}$} & Savia Peru & $\begin{array}{l}\text { Churches (Catholic, Jehova's } \\
\text { Witnesses, Protestants, Christians) }\end{array}$ & Newcastle University \\
\hline & Petrolero Monterico & Local radio & $\begin{array}{l}\text { Engineers without } \\
\text { Borders UK }\end{array}$ \\
\hline \multirow[t]{2}{*}{ Municipality of Talara } & Ipsos Peru & Ecoswell & \\
\hline & New Energy Ventures & Waves for Development & Canada \\
\hline $\begin{array}{l}\text { Regional Government } \\
\text { of Piura }\end{array}$ & Nube9 & Lobitos Cinema Project & York University \\
\hline $\begin{array}{l}\text { Regional Office of } \\
\text { Agriculture }\end{array}$ & Ecomania & High Tides International & \\
\hline \multirow{2}{*}{$\begin{array}{l}\text { Natural Ressources } \\
\text { Management }\end{array}$} & La Republica & Coast 2 Coast & \\
\hline & & $\begin{array}{l}\text { Vaso de Leche Association } \\
\text { of Lobitos }\end{array}$ & \\
\hline National government & $\begin{array}{l}\text { Hotels and restaurants in Lobitos (50+ hotels, } \\
20 \text { directly working with EcoSwell) }\end{array}$ & Transporters Organization of Lobitos & \\
\hline Ministry of Environment & La Casona & Lobitos Primary School & \\
\hline $\begin{array}{l}\text { Ministry of Energy and } \\
\text { Mining }\end{array}$ & Navego & Lobitos Secondary School & \\
\hline Serfor & La Casa de Nacho & Piedritas Primary School & \\
\hline Ministry of Culture & El Hueco Villas & Ecologica Tallang & \\
\hline Imarpe & Cafe Lobitos & Arocha & \\
\hline ProBono & Lobitos Beach House & Lobitos Ocean Adventure & \\
\hline \multirow[t]{2}{*}{$\begin{array}{l}\text { Congress of the } \\
\text { Republic }\end{array}$} & Zion Hotel & & \\
\hline & Hotel Relajate & & \\
\hline \multicolumn{4}{|l|}{ Military forces } \\
\hline $\begin{array}{l}\text { First Infantry Brigade } \\
\text { of Sullana }\end{array}$ & NGOs and associations & & \\
\hline $\begin{array}{l}\text { Special Commando } \\
\text { Forces of Lobitos }\end{array}$ & Sociedad Peruana de Derecho Ambiental & & \\
\hline Talara Navy Office & $\begin{array}{l}\text { National Surfing Association (Fenta) } \\
\text { soS Cortarrama Peruana }\end{array}$ & & \\
\hline $\begin{array}{l}\text { International } \\
\text { organisations }\end{array}$ & Storage Data & & \\
\hline \multirow{3}{*}{$\begin{array}{l}\text { British Chamber of } \\
\text { Commerce in Peru }\end{array}$} & Waves 4 Water & & \\
\hline & WindAid Institute & & \\
\hline & Digicell Foundation & & \\
\hline
\end{tabular}

the ground surface. It does highlight, however, the risk posed by climate conditions on such solutions, and in this case, the proposed solution was to plant increased vegetation such as vetiver grass or other species (while considering the length of the roots to ensure they that they will not affect the pipes) to prevent further loss of soil and improve slope stabilisation.

\section{Conclusions}

The paper has presented factors that have influenced the operation of wastewater treatment systems within the context of Lobitos, Peru. The inadequate service provided by the municipality, which results in wastewater ponds in various points of the community, has highlighted the opportunities of moving into Dewats to 
provide a more resilient and sustainable way of treating wastewater. The infrastructure of the municipal sewerage system is ageing and there are no end-of-the-pipe facilities to treat the wastewater. The solution is to collect wastewater at septic tanks or in open-surface ponds, which are pumped out regularly by a private company paid by the municipality to remove and treat the wastewater. This is inefficient and costly, as well as results in health risks with the wastewater staying exposed for a long period of time among the community and causes environmental pollution and contamination.

As a possible solution, biodigesters were installed by a local NGO in the past as forms of Dewats. These were unsuccessful, due to the lack of understanding in the ways in which the locals would want to use the effluent, as well as overlooking communication and participation of the locals into the project. The community members were not informed on the fact that the effluent was not appropriate for surface irrigation, as the wastewater was not treated to the full extent and therefore used it for watering their garden. This caused health risks, particularly for the children who usually carried the water. The lack of skilled workforce to install the biodigester meant that it caused unpleasant odours which are not acceptable by the community.

For these reasons, it is important to consider the technical feasibility, the quality of installation and the practicality of operation and maintenance for the context in which such solutions are implemented. Further to these points, it is important to develop knowledge and understanding of users and the wider community. In understanding the impacts of what happens when the systems are not maintained, as well as the health hazards posed by open pools of sewage, the wider network of systems are more likely to succeed and provide greater resilience for the community.

These considerations were employed in the new biodigester project implemented by the authors. The FG was chosen as the location where the biodigester would be installed, as it is an important landmark building in the community; it belongs to the only grassroots organisation in the town, and the aspiration is that it can therefore act as a showcase example for the whole community and the wider region. The fishermen were consulted as the primary stakeholders but were also involved in the whole project cycle, as a way of establishing ownership of the infrastructure and responsibility of operation and maintenance to ensure the long-term use of the biodigester. The first results are positive, with the fishermen displaying pride for owning the biodigester at their guild and expressing appreciation of the improvements it makes in waste management. Irrigation is also successful, as indicated by the growth of the planted trees that use the biodigester effluent. It is argued that only through concerted consideration for the social, environmental and economic impacts of this change that such schemes will bring a successful solution for Lobitos. For this change to be sustainable, it is vital that it is carried out in a managed way and that the existing needs of the community and other local stakeholders are addressed. It is recognised that other Dewats solutions, such as wastewater ponds, could be employed in the future as well, providing equal results and benefits, and will be considered for further projects.

\section{Contributions to the field}

The findings of this paper address issues in the town of Lobitos and analyse how these influence wastewater treatment in this context. These findings add to the existing knowledge of the use of Dewats in remote areas, specifically the use of biodegesters, demonstrating how failure to include the local community in the operation of the technology can result in negative outcomes, such as inappropriate use of the effluent, resulting in increased health risk.

\section{Acknowledgements}

The authors would like to acknowledge all of those who support EcoSwell's work, as well as the Fishermen's Guild of Lobitos. The primary author would also like to thank the Engineering and Physical Sciences Research Council (grant reference number $1549455)$ for the financial support in participating in this research.

\section{REFERENCES}

Abraham J, Cheng L and Mann ME (2017) Briefing: Future climate projections allow engineering planning. Proceedings of the Institution of Civil Engineers - Forensic Engineering 170(FE2): 54-57, https:// doi.org/10.1680/jfoen.17.00002.

An BX, Preston TR and Dolberg F (1997) The introduction of low-cost polyethylene tube biodigesters on small scale farms in Vietnam. Journal for Livestock Research for Rural Development 9(2).

Asano T and Cotruvo JA (2004) Groundwater recharge with reclaimed municipal wastewater: health and regulatory considerations. Water Research 38(8): 1941-1951, https://doi.org/10.1016/j.watres.2004.01. 023.

Balkema AJ, Preisig HA, Otterpohl R et al. (2002) Indicators for the sustainability assessment of wastewater treatment systems. Urban Water 4(2): 153-161, https://doi.org/10.1016/S1462-0758(02)00014-6.

Bartram J and Baum R (2015) Introduction. In Routledge Handbook of Water and Health (Bartram J (ed.)). Routledge, London, UK, pp. 1-12.

Bartram J and Cairncross S (2010) Hygiene, sanitation, and water: forgotten foundations of health. PLoS Medicine 7(11): 1-9, https://doi. org/10.1371/journal.pmed.1000367.

Baum F, MacDougall C and Smith D (2006) Participatory action research. Journal of Epidemiology \& Community Health 60: 854-857, http://dx. doi.org/10.1136/jech.2004.028662.

Burt Z, Nelson K and Ray I (2016) Towards Gender Equality through Sanitation Access. UN Women, New York, NY, USA.

Cairncross S, Hunt C, Boisson S et al. (2010) Water, sanitation and hygiene for the prevention of diarrhoea. International Journal of Epidemiology 39(Suppl. 1), https://doi.org/10.1093/ije/dyq035.

Carter RC, Tyrrel SF and Howsam P (1999) Impact and sustainability of community water supply and sanitation programmes in developing countries. Journal of the Chartered Institution of Water and Environmental Management 13(August): 292-296, http://dx.doi.org/ 10.1111/j.1747-6593.1999.tb01050.

Garfí M, Flores L and Ferrer I (2017) Life cycle assessment of wastewater treatment systems for small communities: activated sludge, constructed wetlands and high rate algal ponds. Journal of Cleaner Production 161: 211-219, http://dx.doi.org/10.1016/j.jclepro.2017.05.116.

Gutterer B, Sasse L, Panzerbieter T et al. (2009a) Designing DEWATS. In Decentralised Wastewater Treatment Systems (DEWATS) and 
Sanitation in Developing Countries. A practical Guide (Ulrich AA, Reuter S and Gutterer B (eds)). Wisconsin Economic Development Corporation, Loughborough University, Loughborough, UK, in association with Bremen Overseas Research and Development Association, Germany, pp. 230-281.

Gutterer B, Sasse L, Panzerbieter T et al. (2009b) Towards comprehensive wastewater and sanitation strategies. In Decentralised Wastewater Treatment Systems (DEWATS) and Sanitation in Developing Countries. A Practical Guide (Ulrich AA, Reuter S and Gutterer B (eds)). Water, Engineering and Development Centre (WEDC), Loughborough, UK, pp. 14-31.

Hazeltine B (2003) Chapter 1: Planning and implementation. In Field Guide to Appropriate Technology (Hazeltine B and Bull C (eds)). Academic Press, London, UK, pp. 17-156.

INEI (Instituto Nacional de Estacistica e Informatica) (2011) Capitulo 22: Departamento Piura. INEI, Lima, Peru. See http://proyectos.inei.gob. pe/web/biblioineipub/bancopub/Est/Lib1044/cuadros/cap22.pdf (accessed 15/02/2018).

L'Heureux ML, Takahashi K, Watkins AB et al. (2017) Observing and predicting the 2015/16 El Niño. American Meteorological Society (July): 1363-1382, https://doi.org/10.1175/BAMS-D-16-0009.1.

Libralato G, Ghirardini AV and Avezzù F (2012) To centralise or to decentralise: an overview of the most recent trends in wastewater treatment management. Journal of Environmental Management 94(1): 61-68, https://doi.org/10.1016/j.jenvman.2011.07.010.

Lijó L, Malamis S, González-García S et al. (2017) Technical and environmental evaluation of an integrated scheme for the co-treatment of wastewater and domestic organic waste in small communities. Water Research 109: 173-185, http://dx.doi.org/10.1016/j.watres.2016.10.057.

Manikutty S (1997) Community participation: so what? Evidence from a comparative study of two rural water supply and sanitation projects in India. Development Policy Review 15(2): 115-140, http://dx.doi.org/ 10.1111/1467-7679.00029.

Massoud MA, Tarhini A and Nasr JA (2009) Decentralized approaches to wastewater treatment and management: applicability in developing countries. Journal of Environmental Management 90(1): 652-659, http://dx.doi.org/10.1016/j.jenvman.2008.07.001.

Moog FA, Avilla HF, Agpaoa EV et al. (1997) Promotion and utilization of polyethylene biodigester in smallhold farming systems in the Philippines. Journal for Livestock Research for Rural Development 9(2).

Petroblogger.com (2013) Historia del Petroleo En El Peru Parte 1. Petroblogger.com. See http://www.ingenieriadepetroleo.com/historiaindustria-petrolera-peru-resumen/ (accessed 13/11/2017).
Rose GD (1999) Community-based Technologies for Domestic Wastewater Treatment and Reuse: Options for Urban Agriculture. International Development Research Centre, Ottawa, Canada.

Sahoo KC, Hulland KRS, Caruso BA et al. (2015) Sanitation-related psychosocial stress: A grounded theory study of women across the life-course in Odisha, India. Social Science and Medicine 139: 80-89, http://dx.doi.org/10.1016/j.socscimed.2015.06.031.

Sanabria J, Bourrel L, Dewitte B et al. (2017) Rainfall along the coast of Peru during strong El Niño events. International Journal of Climatology, http://dx.doi.org/10.1002/joc.5292.

Sánchez JR (2013) Plan de desarrollo urbano del distrito de Lobitos provincia de Talara, departamento de Piura: Caracterizacion y diagnostic. Talara, Peru.

Slangen ABA, Adloff F, Jevrejeva S et al. (2016) A review of recent updates of sea-level projections at global and regional scales. Surveys in Geophysics 38(1): 385-406, http://dx.doi.org/10.1007/s10712-0169374-2.

Taj M (2017) Abnormal El Nino in Peru Unleashes Deadly Downpours; More Flooding Seen. Reuters, London, UK. See https://www.reuters.com/ article/us-peru-floods/abnormal-el-nino-in-peru-unleashes-deadlydownpours-more-flooding-seen-idUSKBN16O2V5 (accessed 15/02/2018).

Thorne P (2017) Briefing: Global surface temperature records: an update. Proceedings of the Institution of Civil Engineers - Forensic Engineering 170(FE2): 50-53, https://doi.org/10.1680/jfoen.17.00001.

Trenberth KE (2011) Changes in precipitation with climate change. Climate Research 47: 123-138, http://dx.doi.org/10.3354/cr00953.

UN (United Nations) (2015) World Urbanization Prospects: The 2014 Revision. UN Department of Economic and Social Affairs, Population Division, New York, USA, Report ST/ESA/SER.A/366

US EPA (2005a) Decentralized Wastewater Treatment Systems - a Program Strategy. US EPA, Cincinnati, OH, USA.

US EPA (2005b) Decentralized Wastewater Treatment: A Sensible Solution. US EPA, Cincinnati, OH, USA. See http://water.epa.gov/ infrastructure/septic/upload/MOU-Intro-Paper-081712-pdf-AdobeAcrobat-Pro.pdf (accessed 15/02/2018).

Vymazal J (2005) Horizontal sub-surface flow and hybrid constructed wetlands systems for wastewater treatment. Ecological Engineering 25(5): 478-490, http://dx.doi.org/10.1016/j.ecoleng.2005.07.010.

World Weather and Climate Information (2016) Climate: Average Monthly Weather in Lobitos, Peru. World Weather and Climate Information. See https://weather-and-climate.com/average-monthlyRainfall-Temperature-Sunshine,lobitos-piura-pe,Peru (accessed 13/11/ 2017).

\section{How can you contribute?}

To discuss this paper, please submit up to 500 words to the editor at journals@ice.org.uk. Your contribution will be forwarded to the author(s) for a reply and, if considered appropriate by the editorial board, it will be published as a discussion in a future issue of the journal. 